\title{
REPRESJE GESTAPO WOBEC ALUMNÓW SEMINARIUM W BLONIU K. TARNOWA. ZE WSPOMNIEŃ KS. PRALATA ADAMA KAŹMIERCZYKA - ŚWIADKA POCZĄTKÓW MECZEŃSKIEJ DROGI BL. KS. ROMANA SITKI
}

Stowa klucze:

ks. Adam Kaźmierczyk, WSD Tarnów, bł. ks. Roman Sitko, II wojna światowa, prześladowania Kościoła

\section{Treść:}

I. Początki formacji seminaryjnej

II. Pierwsze formy prześladowania

III. Okoliczności aresztowania

IV. W drodze do więzienia

V. „Będziecie rozstrzelani”...

VI. W więziennych celach

VII. Przesłuchania

VIII. Spotkanie z ks. rektorem Romanem Sitką

IX. Uwolnienie $\mathrm{z}$ więzienia

Szczególna to łaska Boża, niezwykła katecheza życiowa, wielkie doświadczenie - być świadkiem historycznego wydarzenia, rozpoczynającego męczeńską drogę bł. ks. Romana Sitki ${ }^{1}$. Adam Kaźmierczyk był wówczas alumnem I roku, gdy w uroczystość Wniebowstąpienia Pańskiego - 22 maja

${ }^{*}$ Ks. Stanisław Gurba, kapłan diecezji sandomierskiej, mgr teologii, doktorant w Instytucie Historii Sztuki KUL.

${ }^{1}$ Ks. Roman Sitko (1880-1942), rektor Wyższego Seminarium Duchownego w Tarnowie od 1936 roku, aresztowany w 1941 roku przez gestapo i przewieziony do niemieckiego obozu koncentracyjnego Auschwitz-Birkenau, gdzie został zamordowany przez gestapowca w 1942 roku (szerzej por.: A. Nowak, Ksiadz Rektor Roman Sitko. Życie, działalność i męczeństwo, Tarnów 1998, s. 57-76). Beatyfikowany przez papieża Jana Pawła II w Warszawie 13 czerwca 1999 roku w grupie 108 polskich męczenników. 
1941 roku, gestapowcy otoczyli kaplicę w Błoniu k. Tarnowa i aresztowali ks. rektora Romana Sitkę wraz z innymi księżmi i alumnami I i V roku studiów ${ }^{2}$. Po wielu latach ks. Prałat wspomina to wydarzenie:

Prawie zakończyło się $w$ kaplicy nabożeństwo poranne, gdy nagle weszło kilku umundurowanych gestapowców. Jeden z nich stanąt $w$ drzwiach, by nikt nie próbowat wyjść z kaplicy, a reszta przeprowadzata rewizje. Przeszukiwano tawki, odsunięto konfesjonat ks. Brudza, a jeden z nich podszedt do tabernakulum, otworzyt je $i$ swoja laska przesuwat puszki, które sie tam znajdowaty. Potem oświadczono nam, że I rok razem z przełożonymi jest aresztowany, $V$ rok jest na razie wolny [...]. W międzyczasie, gdy byliśmy jeszcze $w$ kaplicy, druga grupa gestapowców zrobiła dokładna rewizje $w$ willi „Ave”. Roztrzepano wszystko i powywracano do góry nogami. Nie znaleziono jednak nic, co by świadczyto na nasza niekorzyść [...]. Kiedy gestapowcy skończyli rewizję $w$ willi „Ave”, ustawiono nas wszystkich $w$ dwuszeregu przed budynkiem [...]. Do Btonia przyjechaty wtedy dwa samochody. Jeden duzy (o ile sobie dobrze przypominam samochód towarowy, z ławkami pośrodku, przystosowany do przewozu pracowników), a drugi osobowy, którym przyjechali gestapowcy. Po skończeniu rewizji załadowano nas na ten samochód. Było nas 22. Razem z nami siadt do samochodu ks. Rektor, Ojciec Duchowny i ks. prof. Julian Piskorz, który miał z nami wykłady. Byt tam jeszcze z wyktadami ks. Jan Paciorek, ale jego nie zabrano. Powiedziano: „,on już byt w więzieniu, my jego znamy”.

Ks. prałat Adam Kaźmierczyk urodził się 18 listopada 1920 roku w Jasieniu k. Brzeska. Wychowywał się w rodzinie wielodzietnej Stanisława i Katarzyny Kaźmierczyków. Spośród sześciorga dzieci, troje wybrało stan duchowny - Adam wybrał kapłaństwo, a jego dwie siostry życie zakonne w zgromadzeniu ss. felicjanek ${ }^{4}$. W 1939 roku Adam zdał maturę w szkole w Brzesku, a następnie wstąpił do Wyższego Seminarium Duchownego w Tarnowie. Święcenia kapłańskie otrzymał 22 kwietnia 1945 roku $^{5}$ z rąk ks. bpa Stanisława Rosponda ${ }^{6}$.

${ }^{2}$ Por. H. Bednarczyk, Więzień - Duszpasterz - Jubilat. Wywiad z ks. prałatem Adamem Kaźmierczykiem, „Wzrastanie” 74-75(1995), s. 12; S. Sojka, Błogosławiony Ksiądz Roman Sitko. Męczennicy 1939-1945, z. 45, Włocławek 2001, s. 17-18.

${ }^{3}$ Archiwum Muzeum Parafialnego w Grybowie (dalej: MPG), Moje kapłaństwo i duszpasterzowanie, [sygn. brak], ks. A. Kaźmierczyk, Nasze uwięzienie - pobyt $w$ tarnowskim więzieniu - odzyskanie wolności, Grybów: 1 marca 2000 rok, maszynopis, s. 2-3.

${ }^{4}$ Por. Zmart ks. Prałat Adam Kaźmierczyk, „Kurier Grybowski” marzec/kwiecień 2004 (5), s. 2; M. Filipowicz-Solarz, Żyć prosto i skromnie. Wspomnienie o księdzu Adamie Kaźmierczyku, w 10-ta rocznicę śmierci. Część I, „Nasza Bazylika” 1(2013), s. 18.

${ }^{5}$ Por. H. Bednarczyk, Więzień-Duszpasterz - Jubilat, dz. cyt., s. 13.

${ }^{6}$ Por. A. Nita (oprac.), Kaptani zmarli w 2004 roku, „Currenda” 1(2005), s. 56. 
Po święceniach rozpoczął pracę duszpasterską jako wikariusz w Ropczycach, od 1948 roku pracował jako wikariusz w Katedrze w Tarnowie, pełniąc równocześnie obowiązki rektora kościoła Matki Bożej Szkaplerznej w Tarnowie oraz kapelana Zakładu Poprawczego w Tarnowie ${ }^{7}$. Dnia 11 marca 1962 roku rozpoczął pracę jako proboszcz parafii pw. św. Katarzyny Aleksandryjskiej w Grybowie. Obowiązki proboszcza wykonywał do roku 1987, kiedy to przeszedł na emeryturę. Przez okres pobytu w Grybowie pełnił funkcję kustosza Muzeum Parafialnego w Grybowie, aż do swojej śmierci 14 stycznia 2004 roku $^{8}$.

Niewiele publikacji zawiera informacje dotyczące wydarzeń związanych z aresztowaniem i uwięzieniem alumna Adama Kaźmierczyka. Wymienić można co najwyżej wywiad przeprowadzony z ks. Prałatem z okazji jego złotego jubileuszu kapłaństwa przez Halinę Bednarczyk ${ }^{9}$ czy ks. Krzysztofa Słowaka ${ }^{10}$. Świadectwa - w większości anonimowe - dotyczące aresztowania i pobytu w więzieniu alumnów z Błonia zostały opublikowane w biografiach bł. ks. Romana Sitki ${ }^{11}$ bądź w formie artykułów autorstwa świadków wydarzenia $^{12}$, czy też ich pisemnych i ustnych zeznan ${ }^{13}$. Zapewne wielu osobom znane są wydarzenia $\mathrm{z}$ życia ks. Kaźmierczyka na podstawie ustnych jego przekazów, gdyż w spotkaniach indywidualnych i w mniejszych grupach ks. Prałat chętnie wspominał minione lata swojego życia. Nigdy nie podzielił się swoimi doświadczeniami ze spotkania z bł. ks. Sitką z szerszą grupą odbiorców $^{14}$. Ks. Prałat wielokrotnie wspominał, że informacje te może przekazać w formie wywiadu lub artykułu. Kilkustronicowy maszynopis wspomnień z czasów kleryckich, autorstwa ks. Adama Kaźmierczyka, zachował się w Archiwum Muzeum Parafialnego w Grybowie.

Celem niniejszego artykułu jest ukazanie represji gestapo wobec alumnów tarnowskiego seminarium i księży w okresie II wojny światowej, na podstawie wspomnień ks. prałata Adama Kaźmierczyka. Kwerendą objęte zostały

${ }^{7}$ Szerzej o pracy ks. Adama Kaźmierczyka w Zakładzie Poprawczym por.: tenże, Kapelan w Zakladzie Poprawczym, „Wzrastanie” 80(1995), s. 10-11.

${ }^{8}$ Zmarl ks. Prałat Adam Kaźmierczyk, s. 2-3.

${ }^{9}$ H. Bednarczyk, Więzień - Duszpasterz - Jubilat, dz. cyt., s. 12-13.

${ }^{10} \mathrm{MPG}$, Moje kapłaństwo i duszpasterzowanie, [sygn. brak], K. Słowak, Złoty jubileusz kapłaństwa. Wywiad z ks. Adamem Kaźmierczykiem (wycinek z prasy - karta luźna), por. ten sam tekst w formie maszynopisu $\mathrm{z}$ dnia 30.04.1995, s. 1-3. s. $19-65$.

${ }^{11}$ S. Sojka, Błogosławiony Ksiadz Roman Sitko. Męczennicy 1939-1945, dz. cyt.,

${ }^{12}$ A. Kmiecik, Wspomnienie o aresztowaniu ks. Rektora Romana Sitki, „Currenda” 3(1996), s. 374-376.

${ }^{13}$ Bibliografia niniejszych pozycji, por. A. Nowak, Ksiadz Rektor Roman Sitko. Życie, działalność i męczeństwo, dz. cyt., s. 133. Zeznania ks. Kaźmierczyka składane w procesie beatyfikacyjnym ks. Romana Sitki w znacznej części pokrywają się z jego autobiograficznymi wspomnieniami spisanymi kilka lat po przesłuchaniach, przechowywanymi w Archiwum Muzeum Parafialnego w Grybowie.

${ }^{14}$ M.in. po ogłoszeniu ks. Romana Sitki błogosławionym (13.06.1999 rok) ks. Adam Kaźmierczyk kilkakrotnie zapraszany był na okazjonalną konferencję dla kleryków w Wyższym Seminarium Duchownym w Tarnowie, w której jednak nie wziął udziału z powodów zdrowotnych. 
archiwalia Muzeum Parafialnego w Grybowie, publikacje ks. Adama Kaźmierczyka we „Wzrastaniu” i „Kurierze Grybowskim”. Głównym tekstem wykorzystanym w artykule jest wspomniany wcześniej maszynopis, zawierający szczegółowy autobiograficzny opis okresu formacji seminaryjnej ks. Prałata. Wykorzystanie tekstu źródłowego, dotychczas nie publikowanego, stanowi nowe spojrzenie na podejmowany temat. Zamierzone jest dosłowne przytaczanie fragmentów tekstu źródłowego, które na tle dotychczasowej wiedzy o wydarzeniach $\mathrm{w}$ tarnowskim seminarium w czasie wojny stają się niezwykle interesujące i stanowią przyczynek do dalszych badań nad omawianym zagadnieniem. Stosunkowo niedługi czas od śmierci ks. Kaźmierczyka (10 lat) sugeruje, że podejmowany temat mógłby zostać uzupełniony o świadectwa ludzi, którzy znali bliżej ks. Prałata, tym bardziej, że w indywidualnych spotkaniach chętnie wspominał on czasy swojej formacji seminaryjnej.

\section{POCZĄTKI FORMACJI SEMINARYJNEJ}

Wybuch wojny we wrześniu 1939 roku postawił pod znakiem zapytania możliwość przygotowania się do kapłaństwa w seminarium w Tarnowie. Już w dniu 7 września 1939 roku gmach Wyższego Seminarium Duchownego w Tarnowie został zajęty przez Niemców. W budynku seminaryjnym mieściła się administracja niemiecka całego powiatu tarnowskiego. Dzięki staraniom ks. rektora Sitki zorganizowano nauczanie alumnów w willi wakacyjnej w Błoniu już w październiku 1939 roku, gdzie w ogromnej ciasnocie zamieszkało stu osób ${ }^{15}$. Ks. Prałat pisze:

Egzamin dojrzałości zdałem w Państwowym Gimnazjum i Liceum w Brzesku w maju 1939 roku. Potem zostałem przyjęty do Seminarium Duchownego $w$ Tarnowie. $W$ polowie czerwca zglositem sie na ochotnika na 2 miesiace do ,junackich hufców pracy”. Atmosfera byta bardzo goraca, zbliżała się wojna światowa [...]. We wrześniu 1939 r. wybuchła II wojna światowa. Niemcy zajęli Polske, dzielą się razem ze Sowietami połowa naszego kraju. Budynek Seminarium Duchownego $w$ Tarnowie zostat zajęty przez Niemców. Studia teologiczne rozpoczęliśmy dopiero wczesną wiosna 1940 roku. Odbyty się one w Błoniu k. Tarnowa, w willi wypoczynkowej dla kleryków tarnowskich [...]. Na pierwszym roku byto nas 33: 14 z malego seminarium $i 19$ chtopców ,ze świata”. W Błoniu nie można było zgromadzić więcej kleryków, bo nie było miejsca. W Błoniu rozpoczęty się wyktady. Ks. rektor Roman Sitko i ojciec duchowny Józef Brudz mieszkali na miejscu. Profesorowie dojeżdżali z Tarnowa ${ }^{16}$.

\footnotetext{
${ }^{15}$ Por. S. Sojka, Błogostawiony Ksiadz Roman Sitko. Męczennicy 1939-1945, dz. cyt., s. 15.

${ }^{16}$ A. Kaźmierczyk, Nasze uwięzienie - pobyt w tarnowskim więzieniu-odzyskanie wolności, dz. cyt., s. 1 .
} 
W momencie rozpoczęcia studiów w 1939 roku warunki nauki w zastępczym budynku seminarium tarnowskiego były ciężkie (ciasnota, brak wody, kanalizacji) pomimo, że w Błoniu mieszkały tylko dwa roczniki I i II $^{17}$. Seminarzyści $\mathrm{z}$ wyższych lat przebywali $\mathrm{w}$ domach, $\mathrm{z}$ których na trzy-cztery miesiące przyjeżdżali na cykle wykładów, potem wracali do rodziny, a ich miejsce zajmował rocznik następny. Wszyscy natomiast zjawiali się na sesje, by złożyć egzaminy i kontynuować studia ${ }^{18}$.

Mieszkaliśmy wtedy [w dniu aresztowania - przyp. red.] $w$ willi „Ave”. Byto nas juz 22, bo $11 \mathrm{w}$ międzyczasie zrezygnowato z seminarium. W Willi „Ave” zajmowaliśmy 3 pomieszczenia. Jedno $z$ pomieszczeń trzymat ks. Rektor Roman Sitko, drugie O. duchowny ks. Józef Brudz, była tam też sala wyktadowa ${ }^{19}$.

Troska kapłanów mieszkających w Błoniu o formację seminarzystów oraz o działania ujawniające prawdę o postępowaniu gestapowców była przez alumnów zauważalna. Ks. rektor Sitko, nie zważając na konsekwencje podejmowanych działań, zatroskany o powołania tak ważne w dalszej przyszłości dla Kościoła i diecezji, za wiedzą biskupa, z narażeniem własnego życia, prowadził nauczanie seminaryjne $\mathrm{w}$ Błoniu ${ }^{20}$. Władzom niemieckim nie podobało się także postępowanie ojca duchownego, ks. Józefa Brudza ${ }^{21}$, który chętnie dzielił się z klerykami wiadomościami z zagranicy:

Wiem, że mial on [ojciec duchowny Józef Brudz - przyp. red.] ukryty aparat radiowy, stuchat wiadomości z zagranicy, czasem nam coś powiedziat, czasem pisat to na maszynie i dawat te notatki niektórym klerykom, aby pożyczajac ksiażki do czytania ludziom $z$ wioski, przy tej okazji przekazywali im te wiadomości $i^{22}$.

${ }^{17}$ Ks. Kaźmierczyk na pierwszym roku mieszkał w sypialni 18-osobowej, wodę klerycy nosili ze studni, myli się w miednicach, toalety były na zewnątrz (por. K. Słowak, Złoty jubileusz kapłaństwa, dz. cyt., karta luźna).

${ }^{18}$ Por. H. Bednarczyk, Więzień-Duszpasterz - Jubilat, dz. cyt., s. 12.

${ }^{19}$ A. Kaźmierczyk, Nasze uwięzienie - pobyt w tarnowskim więzieniu - odzyskanie wolności, dz. cyt., s. 2.

${ }^{20}$ Por. S. Sojka, Błogosławiony Ksiądz Roman Sitko. Męczennicy 1939-1945, dz. cyt., s. $16-17$.

${ }^{21}$ Ks. Józef Brudz (1912-1985) został mianowany ojcem duchownym w WSD w Tarnowie w 1938 roku. Został aresztowany wraz z ks. Romanem Sitka, przeszedł przez tarnowskie więzienie, obozy koncentracyjne w Gross-Rosen, Oświęcimiu i Dachau, potem wrócił do seminarium i jeszcze kilkadziesiąt lat pracował w charakterze prefekta i profesora (por. A. Nowak, Ksiądz Rektor Roman Sitko. Życie, działalność i męczeństwo, dz. cyt., s. 57).

${ }^{22}$ A. Kaźmierczyk, Nasze uwięzienie - pobyt w tarnowskim więzieniu - odzyskanie wolności, dz. cyt., s. 2. 
Mimo tych i innych trudności - wspomina ks. Prałat - „,czuliśmy się szczęśliwi, gdyż byliśmy zdrowi, nie chodziliśmy głodni i mogliśmy się uczyć" 23 .

\section{PIERWSZE FORMY PRZEŚLADOWANIA}

Chociaż ks. Rektorowi udało się zorganizować już w październiku 1939 roku studia dla kleryków w Błoniu, problemy się nie skończyły. Władze niemieckie, powiadomione o tym, że „klerycy uzupełniają wykształcenie liturgiczne" przed święceniami, podejrzewały, że w Błoniu odbywa się normalne studium teologii. Władze okupacyjne postanowiły zamknąć od dnia 31 października 1939 roku wszystkie polskie uczelnie wyższe, w tym seminaria (w niemieckiej interpretacji w Krakowie i Sandomierzu można było dokończyć studia teologiczne alumnów). W dniu 21 września 1940 roku władze okupacyjne formalnie zakazały przyjmowania nowych kandydatów do seminarium. Ks. Rektor jednak postanowił kontynuować nauczanie w Błoniu ${ }^{24}$. Może miał to być sposób na przekonanie władz niemieckich do swojej racji. Wszystko jednak zgodnie z prawem, by nie dać powodu władzom państwowym do niechęci wobec seminarzystów ${ }^{25}$. Choć klerycy czuli się dobrze mieszkając $\mathrm{w}$ skromnych warunkach w Błoniu, ich radość $\mathrm{z}$ nowo obranej drogi życiowej nie trwała długo.

Te studia [rozpoczęte wczesna wiosna 1940 r. - przyp. red.] trwaty bardzo krótko, bo zaledwie miesiac. Władze niemieckie zabronity dalszych studiów i musieliśmy wyjechać do domu. Powiedziano nam, żebyśmy $w$ domu przerobili materiat i przygotowali się do egzaminu, bo będziemy poproszeni z powrotem w odpowiednim czasie ${ }^{26}$.

Obietnice władz seminaryjnych zostały wkrótce spełnione - klerycy po półrocznej przerwie wrócili do domu formacyjnego w Błoniu, ale również nie na długo:

Poproszono nas powtórnie dopiero w październiku. Byliśmy wtedy razem z II rokiem. Ten pobyt trwat zaledwie kilkanaście dni. Wtadze niemieckie przeprowadzity $w$ Błoniu rewizje $i$ choć nie znaleziono niczego kompromitujacego, odestano nas do domu ${ }^{27}$.

\footnotetext{
${ }^{23}$ H. Bednarczyk, Więzień - Duszpasterz - Jubilat, dz. cyt., s. 12; por. K. Słowak, Złoty jubileusz kaptaństwa, dz. cyt., karta luźna.

${ }^{24}$ Por. S. Sojka, Błogostawiony Ksiądz Roman Sitko. Męczennicy 1939-1945, dz. cyt., s. $15-17$.

${ }^{25}$ Por. M. Filipowicz-Solarz, Żyć prosto i skromnie. Wspomnienie o księdzu Adamie Kaźmierczyku, w 10-ta rocznice śmierci. Czesść I, dz. cyt., s. 18.

${ }^{26}$ A. Kaźmierczyk, Nasze uwięzienie - pobyt w tarnowskim więzieniu - odzyskanie wolności, dz. cyt., s. 1 .

${ }^{27}$ Tamże, s. 1-2.
} 
Trzeci przyjazd ks. Kaźmierczyka do Błonia był już ostatnim, gdy alumnów witał ks. rektor Sitko. Tym razem również alumni nie wrócili do domów rodzinnych:

Przyjechaliśmy po raz trzeci wczesna wiosna 1941 roku. Razem z nami byli klerycy z V roku studiów ${ }^{28}$.

\section{OKOLICZNOŚCI ARESZTOWANIA}

Najmocniejsza fala prześladowań odczuwalna przez kleryków dała się we znaki w maju 1941 roku, gdy cały I rok, ks. Rektor i Ojciec Duchowny oraz dostarczajacy mięso klerykom - Stanisław Korman zostali aresztowani przez władze niemieckie i osadzeni $\mathrm{w}$ tarnowskim więzieniu. Wówczas to klerycy na własnej skórze doświadczyli okrutnego postępowania gestapowców oraz bohaterskiej postawy swoich przełożonych:

Przechodzac [w dniu aresztowania - przyp. red.] obok jednej sypialni (przechodzitem z moim kolega ks. Franciszkiem Klimasem), styszeliśmy, jak jeden gestapowiec bit ks. Rektora laska. A on krzyczat: „O Jezu! O Matko Boska!”. W pewnym momencie uderzyt go w okulary i rozbit mu je. Wiem, że wyszedt stamtąd sponiewierany ${ }^{29}$.

Sami klerycy w dniu aresztowania przeżywali chwile trwogi, ponieważ wartownicy popychali ich, strzelali, aby ich zastraszyć, lżyliª:

Kiedy gestapowcy skończyli rewizje w willi „Ave”, ustawiono nas wszystkich $w$ dwuszeregu przed budynkiem. Tam ubliżano nam, wołajac po niemiecku: ,, wy przeklęte klechy”. Raz po raz strzelano $w$ górę z karabinów nad naszymi głowami ${ }^{31}$.

Żeby aresztować, nie potrzebne były oskarżenia. Był to bowiem czas nieludzki. Polaków, nie mówiąc o Żydach, księżach, więziono, zabijano za to, że byli Polakami, księżmi, Żydami ${ }^{32}$ :

[Podczas rewizji w willi „Ave” - przyp. red.] nie znaleziono jednak nic, co by świadczyto na nasza niekorzyść. Przeprowadzono również rewizję w pokoju ks. Rektora i O. Duchownego. U ks. Rektora nie znaleziono również nic. Nie wiem, jak było z ks. Brudzem. Wiem, że miat on ukryty aparat radiowy ${ }^{33}$.

\footnotetext{
${ }^{28}$ Tamże, s. 2.

${ }^{29}$ Tamże.

${ }^{30}$ Por. H. Bednarczyk, Więzień-Duszpasterz-Jubilat, dz. cyt., s. 12.

${ }^{31}$ A. Kaźmierczyk, Nasze uwięzienie - pobyt w tarnowskim więzieniu - odzyskanie wolności, dz. cyt., s. 2-3.

${ }^{32}$ Por. H. Bednarczyk, Więzień-Duszpasterz - Jubilat, dz. cyt., s. 12.

${ }^{33}$ A. Kaźmierczyk, Nasze uwięzienie - pobyt w tarnowskim więzieniu - odzyskanie
} wolności, dz. cyt., s. 2. 


\section{W DRODZE DO WIEZZIENIA}

Nalot gestapowców zakończył się aresztowaniem ks. rektora Romana Sitki, ojca duchownego - ks. Józefa Brudza, ks. prof. Juliusza Piskorza i dwudziestu dwóch kleryków ${ }^{34}$. Samochodami mieli oni zostać przewiezieni do Tarnowa.

Po załadowaniu nas na samochód kilku gestapowców, chyba 4, wsiadto razem z nami. $W$ rękach mieli krótkie karabiny i powiedzieli nam: „Kopf nieder” (głowa w dót) i oświadczyli: jeśli ktoś $z$ nas podniesie glowę do góry, będzie zastrzelony. Ruszyliśmy $w$ kierunku Tarnowa. Niedlugo jednak samochód ugrzazł na drodze, bo droga byta gliniasta, a niedawno padało. Wtedy musieliśmy wyjść z samochodu i pchać go po tej drodze. Nie daliśmy jednak rady. Wszyscy byliśmy ogromnie wysmarowani glina, a oni bili nas pejczami, czasem kopnęli kogoś z nas $i$ wołali: prego, prego! Nie zaprzątnęli jednak do tej roboty ks. Rektora i 2 profesorów. Pomagat nam również $V$ rok. Kiedy jednak to nie pomogło, przyniesiono $z$ wioski kilkanaście siekier $i$ wycinaliśmy gałęzie na przydrożnych wierzbach, a byto ich tam kilkanaście, i ktadli pod koła samochodu. I to jednak nie przydało się na nic. Samochód nie ruszyl. Czekaliśmy dość sporo, aż wreszcie przyjechat jakiś ciagnik $i$ wyciagnąt nas $z$ tego blota ${ }^{35}$.

Po tym wydarzeniu grupa transportowanych do Tarnowa pomniejszyła się o kleryków z V rocznika:

Koledzy z V rocznika zostali wtedy odestani do Btonia i powiedziano im: jesteście internowani i przez 10 dni nie wolno wam opuszczać Błonia. Jeśli ktoś $z$ was to zrobi, czeka go więzienie ${ }^{36}$.

\section{V. „BĘDZIECIE ROZSTRZELANI”...}

Samochód $\mathrm{z}$ aresztowanymi dotarł do siedziby gestapo w Tarnowie przy ul. Urszulańskiej. Alumni przeżywali wówczas momenty grozy, gdyż ustawiono ich z podniesionymi rękami na podwórzu pod murem i oświadczono, że zostaną rozstrzelani. Kilkakrotnie odliczano, padały strzały, ale nikt nie został trafiony ${ }^{37}$ :

\footnotetext{
${ }^{34}$ Por. H. Bednarczyk, Więzień - Duszpasterz-Jubilat, dz. cyt., s. 12.

${ }^{35}$ A. Kaźmierczyk, Nasze uwięzienie - pobyt w tarnowskim więzieniu - odzyskanie wolności, dz. cyt., s. 3 .

${ }^{36}$ Tamże.

${ }^{37}$ Por. H. Bednarczyk, Więzień-Duszpasterz-Jubilat, dz. cyt., s. 12.
} 
W końcu przywieziono nas do Tarnowa na ulice Urszulańska, do budynku gestapo. Wprowadzono nas do środka i schodami $w$ dót zeszliśmy na podwórze. Tam ustawiono nas po dwóch naprzeciw piwnicznych okien. Widzieliśmy w nich [w szybach okiennych przyp. red.], co się dzieje. Powiedziano nam: „,eraz będziecie rozstrzelani". Za nami na podwyższeniu ustawiło się może 10 gestapowców z karabinami, gotowi do strzalu. Myślimy sobie: „, to pewnie będzie koniec". Każdy z nas przeżegnat się $i$ wzbudzit sobie żal doskonaty. I myślę sobie: , będzie to, co Bóg da”. I zaczęto się odliczanie: ein, zwei, drei-feuer: $i$ wtedy rozlegaty się strzaty. Strzelali oczywiście w powietrze. Tak odliczano jeszcze dwukrotnie. A myśmy nie wiedzieli, co będzie dalej ${ }^{38}$.

W rezultacie klerycy zostali „tylko” pobici nahajkami i kolbami. Potem odtransportowani do tarnowskiego więzienia ${ }^{39}$ :

Następnie powiedziano nam: „Idziemy z powrotem do samochodu”. Gestapowcy zrobili dwuszereg. A środkiem kazali nam iść do samochodu. Bili przy tym okrutnie każdego, gdzie popadto. Bili pięściami i pejczami. Po karku, po rękach, po nogach, bili kolbami od karabinów i kopali, ile sie dato. Nikt z nas nie doznat jakichś poważnych obrażeń, ale wielu z nas miało przez szereg nastęnych dni since na karku, na rękach i nogach ${ }^{40}$.

\section{W WIĘZIENNYCH CELACH}

Brudni i wyczerpani po trudach transportu z Błonia do Tarnowa, pobici i zastraszeni po doświadczeniach w budynku gestapo, aresztanci zostali odtransportowani do tarnowskiego więzienia.

Siedzieliśmy $w$ trzech celach. $W$ mojej celi, która była na piętrze (nie pamiętam, czy na I czy na II), byto nas 8: siedmiu kleryków i cywil, Stanistaw Korman z Btonia, który dostarczal dla kleryków mięso, wędliny $i$ nabiat. On też zostat aresztowany razem z nami pod zarzutem prowadzenia nielegalnego uboju. Taki sam zarzut postawiono ks. Rektorowi Romanowi Sitce, choć byto wiadomo, że Korman doktadnie wywiazywat się $z$ natożonego kontyngentu $i$ sprzedawat nam to, co zbywato.

\footnotetext{
${ }^{38}$ A. Kaźmierczyk, Nasze uwięzienie - pobyt $w$ tarnowskim więzieniu - odzyskanie wolności, dz. cyt., s. 3-4.

${ }^{39}$ Por. H. Bednarczyk, Więzień - Duszpasterz - Jubilat, dz. cyt., s. 12.

${ }^{40}$ A. Kaźmierczyk, Nasze uwięzienie - pobyt w tarnowskim więzieniu - odzyskanie wolności, dz. cyt., s. 4.
} 
Koledzy wybrali mnie komendantem celi. Każdego rana, po otwarciu celi, meldowatem słowami (oczywiście po niemiecku): „Melduję cele $n r$ 87. Osiem osób. Wszyscy zdrowi”. Reszta kleryków (a byto nas $w$ sumie 22) byta umieszczona $w$ dwóch innych celach. Mieli też cele wspólne. Wiem, że ks. Rektor Roman Sitko siedziat na pojedynce. I rozpoczęło się ciężkie i przykre życie więzienne ${ }^{41}$.

Życie w więzieniu łatwe nie było. Hitlerowcy nie dopuszczali żadnej pomocy, a racje żywnościowe były głodowe ${ }^{42}$. Wielu tak osłabło, że nie było w stanie ustać na nogach. Dopiero po dwóch miesiącach, dzięki opiece społecznej, w której działał m.in. ks. Karol Pękala, późniejszy biskup pomocniczy w Tarnowie, żywienie poprawiło się nieznacznie, co pomogło klerykom przyjść w jakimś stopniu do siebie ${ }^{43}$.

Ale po miesiącu coś się zmieniło na lepsze. Tzw. „opieka społeczna”, na czele której stat ks. Karol Pękala [...], wystarała się o to, że raz $w$ tygodniu $w$ każdy czwartek otrzymaliśmy ćwiartkę małego chleba $i$ chochle dobrej tlustej zupy. Kiedy otrzymaliśmy to po raz pierwszy, powiedziatem naszym chtopakom: „Nie można jeść wszystkiego od razu. Trzeba zjeść odrobinę, a resztę zatrzymać na dalsze dni, bo nasze żoładki sa wygtodzone i może być źle”. Tak się rzeczywiście stało. $W$ sąsiednich celach więźniowie polityczni zjedli wszystko od razu. $W$ nocy styszeliśmy straszliwe krzyki $i$ jęki. Niektórzy z nich dostali skrętu kiszek. Tej nocy zmarlo z tego powodu 8 więźniów ${ }^{44}$.

Życie więzienne było też szkołą formacji młodych chłopców. Nie tylko heroiczne postawy przełożonych seminaryjnych były budujące dla alumnów, ale także dobroć, której doświadczyli ze strony thumaczy podczas przesłuchań, strażników więziennych, służby więziennej oraz osób niosących pomoc z zewnątrz.

Pod koniec naszego pobytu $w$ więzieniu zdarzyło się kilkakrotnie, że nagle otwarła się cela $i$ weszło dwóch mechaników, przyprowadzonych przez strażnika. Byli to karni więźniowie, którzy rzekomo mieli sprawdzić rury centralnego ogrzewania. $W$ dużm pudle przynosili narzędzia, smary i bardzo wiele pakut. Pod pakułami byt zwyczajnie bochenek chleba. Postukali troche po rurach, wyjmowali bochenek chleba i czym prędzej wychodzili z celi ${ }^{45}$.

\footnotetext{
${ }^{41}$ Tamże.

${ }^{42}$ Por. K. Słowak, Złoty jubileusz kapłaństwa, dz. cyt., karta luźna.

${ }^{43}$ Por. H. Bednarczyk, Więzień-Duszpasterz-Jubilat, dz. cyt., s. 12.

${ }^{44}$ A. Kaźmierczyk, Nasze uwięzienie - pobyt w tarnowskim więzieniu - odzyskanie wolności, dz. cyt., s. 5.

${ }^{45}$ Tamże, s. 7.
} 
Więźniowie mogli także liczyć na pomoc duchową - choć też „dostarczaną" potajemnie. Alumni byli przekonani, że modli się w ich intencji rektor - ks. Roman i wiele innych osób. Sami też wspólnie modlili się w celi:

Modliliśmy się wszyscy wspólnie rano. Przy pacierzu odmawialiśmy też litanię do Matki Bożej i I część różańca. W poludnie: Aniot Pański i część II różańca. Wieczorem część III i nasze modlitwy wieczorne. Modliliśmy się serdecznie i szczerze proszac Pana Boga, aby nam przyszedt z pomoca. Nie śpiewaliśmy żadnych pieśni, bo nie wolno byto śpiewac ${ }^{46}$.

Cotygodniowe wyjścia do łaźni alumni traktowali jako okazję, aby zobaczyć się z innymi więźniami i porozmawiać na temat pytań zadawanych przy przesłuchaniach. Podobny cel miały wizyty u więziennego lekarza, tu dodatkowo była okazja do skorzystania także z sakramentu pokuty:

Co pewien czas zgłaszaliśmy się do więziennego lekarza. Nawet nie $z$ powodu choroby, ale po to, aby się zobaczyć i trochę cichcem porozmawiać. Niektórzy, stojac w kolejce do lekarza, spowiadali się, gdy natrafit się jakiś ksiądz. Dość często przychodzit tam ks. Julian Piskorz. Strażnik więzienny, który nas pilnowat, zdawat się wielu rzeczy nie widzieć i nie styszeć. Lekarz więzienny miat na wszystko jednakowe lekarstwo [...] - kazdy dostawat jednakowe pastylki, które rzekomo miały pomagać na wszystko ${ }^{47}$.

\section{PRZESŁUCHANIA}

W czasie przesłuchań alumni, będący więźniami politycznymi, byli nieco lepiej traktowani niż inni.

Pewnego dnia, a byto to $w$ jakiś poniedziatek, przewieziono nas pięciu z rana $z$ więzienia na gestapo, na ul. Urszulańska i rozpoczęto się przestuchanie. Przestuchiwano nas przez tlumacza, który nazywat się Holm. Jeden ze strażników więziennych, nazwiskiem Szerszeń, powiedziat mi, że to jest dobry człowiek, który ratuje więźniów, a pochodzi z wioski Gołkowice k. Sacza. Była to dawna kolonia niemiecka. Kiedy przyjechaliśmy na gestapo, czterech $z$ nas postawit $w$ dużym pokoju (każdego w innym kacie) $i$ otworzyt drzwi do pokoju, w którym odbywaty sie przestuchania. Trzech gestapowców siedziato za stotem [...]. Holm przestuchiwat osobno każdego z nas. Stawiat pytania bardzo głośno i kazat głośno odpowiadać, tak aby wszyscy slyszeli, jak należy mówić. Jakaś sekretar-

\footnotetext{
${ }^{46}$ Tamże, s. 6.

${ }^{47}$ Tamże, s. 7.
} 
ka, siedzaca obok, spisywata wszystko na maszynie. Przestuchiwanie odbywało się bardzo spokojnie. Nikogo z nas nie bito, nie rozstrzelano. Nikt się do niczego nie przyznat. Potem podpisaliśmy protokót i zostaliśmy przetransportowani do więzienia ${ }^{48}$.

Klerycy podczas przesłuchań pytani byli o przynależność do jakiejś tajnej organizacji wśród kleryków w Błoniu, o wiedzę dotyczącą posiadania przez ks. J. Brudza radia i przekazywania innym wiadomości z zagranicy - na wszystkie pytania klerycy odpowiadali przecząco. Pytano również o ks. rektora Sitkę: skąd brał żywność dla kleryków ${ }^{49}$ :

Niewiele mogliśmy na ten temat powiedzieć, bo ks. Rektor nigdy nam o tym nic nie mówit ${ }^{50}$.

\section{SPOTKANIE Z KS. REKTOREM ROMANEM SITKĄ}

Ks. Roman Sitko byt na oddziale karnym. Siedziat w pojedynce. Zarzucano mu to, że prowadzit nielegalny ubój, chcac wyżywić kleryków przebywajacych $w$ Błoniu $k$. Tarnowa. Osobiście nigdy się $z$ nim nie widziałem. Raz tylko strażnik więzienny Szerszeń, idac $z$ więźniami do taźni, na życzenie ks. Mariana Krężla, otworzyt cele ks. Rektora. Rozmawiali chwilę. Ks. Rektor byt jakiś wyciszony $i$ spokojny. Pozdrowit nas wszystkich i mówit, że się ustawicznie modli $w$ naszej intencji. Zachęcat tez do wytrwania. W czasie naszego trzymiesięcznego pobytu $w$ więzieniu dwa razy przesłał nam przez strażnika ,gryps”, w którym pocieszat nas, mówit, że bierze wszystko na siebie, zapewniat o modlitwie i prosit, by modlić się również w jego intencji ${ }^{51}$.

\section{UWOLNIENIE Z WIĘZIENIA}

Klerycy (22), wraz z ks. prof. Julianem Piskorzem i panem Kormanem z Błonia, zostali uwolnieni 3 września 1941 roku, a ks. Rektora i Ojca Duchownego wywieziono do Oświęcimia ${ }^{52}$.

Potem zebrano nas wszystkich na więziennym „kwadracie”. Byt tam naczelnik więzienia i ttumacz Holm. Kiedy ustawiliśmy się $w$ dwuszeregu, naczelnik więzienia powiedziat nam: „Jesteście wolni, ale każdy z was, przebywając na wolności, będzie się musiat

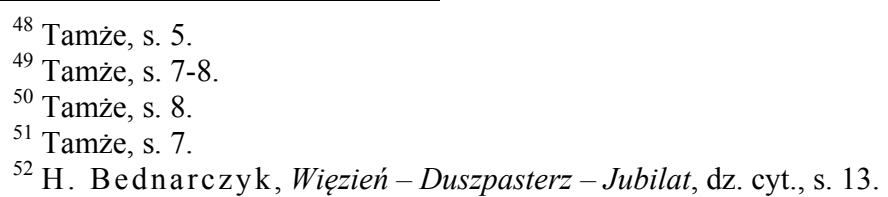


meldować $w$ najbliższym niemieckim posterunku policyjnym, $w$ każdy pierwszy poniedziatek miesiaca. I tak, aż do odwołania”. Potem naczelnik więzienia postawił nam pytanie, oczywiście po niemiecku, a Holm tlumaczyt: „Jak wam tutaj byto?”. Nie mówiliśmy nic [...]. , ,Jeślibyście powiedzieli, co się tutaj działo i jak wam tutaj było, wyjdziecie na wolność w Oświęcimiu, ale kominem ",53.

Ale więzienie spowodowało przerwę w studiach oraz to, że grupa kleryków I roku zmniejszyła się (m.in. dwóch kolegów niedługo po wyjściu $\mathrm{z}$ więzienia zmarło na gruźlicę) $)^{54}$.

Po roku Gestapo zwolniło nas z obowiazku meldowania. Nowy rektor, ks. Władystaw Wegiel, otrzymat zezwolenie na dalsze prowadzenie seminarium. Byto to chyba z poczatkiem października 1942 roku. Przyjechaliśmy do Tarnowa. Byto nas tylko dwunastu [...] Studiowaliśmy razem z kolegami z drugiego roku w tzw. „Pałacu Biskupim” w Tarnowie, przy ul. Mościckiego 9 (seminarium byto zajęte przez Niemców). Warunki byly bardzo ciężkie: wielka ciasnota, marne wyżywienie, ciagły strach - ale nikt nie narzekat. Cieszyliśmy się, że możemy uczyć się dalej i zblizać ku kapłaństwu ${ }^{55}$.

Tylko dzięki samozaparciu, intensywnej pracy, bez ferii i wakacji, klerycy w dwa i pół roku opanowali materiał przewidziany na cztery lata studiów. Dzięki temu, po odpowiednim przygotowaniu, 22 kwietnia 1945 roku dwunastu nowych kapłanów (wśród nich Adam Kaźmierczyk) oddało swe życie na służbę Ewangelii ${ }^{56}$.

${ }^{53}$ A. Kaźmierczyk, Nasze uwięzienie - pobyt $w$ tarnowskim więzieniu - odzyskanie wolności, dz. cyt., s. 8.

${ }^{54}$ Por. H. Bednarczyk, Więzień - Duszpasterz - Jubilat, dz. cyt., s. 13.

${ }^{55}$ A. Kaźmierczyk, Nasze uwięzienie - pobyt $w$ tarnowskim więzieniu - odzyskanie wolności, dz. cyt., s. 9 .

${ }^{56}$ H. Bednarczyk, Więzień-Duszpasterz-Jubilat, dz. cyt., s. 13. 


\section{REPRESSION AGAINST SEMINARY STUDENTS IN BŁONIE NEAR TARNÓW BY THE NAZIS. \\ BASED ON THE MEMOIRS OF FATHER ADAM KAŹMIERCZYK - THE WITNESS OF THE BEGINNINGS OF MARTYRDOM OF BLESSED FATHER ROMAN SITKO}

\section{Summary}

Father Adam Kaźmierczyk (1920-2004), as a student of the first year of the Seminary in Tarnów, was one of the people arrested on April 22, 1941 by the Nazis in Błonie near Tarnów. He was thus an eyewitness to the beginning of martyrdom of the rector, Fr. Roman Sitko - now blessed. This article has cited the memories of Fr. Adam concerning his seminary formation, which was interrupted for 100 days due to his arrest and imprisonment in Tarnów. These facts may partly be revealed in the previously published interviews of Fr. Kaźmierczyk, or known for a certain group of people from his oral tradition. Some events can be aligned with the memories of the witnesses of Fr. Roman Sitko's arrest, available in the publications devoted to the Blessed Father. Any such information is valuable and sheds light on the issue of repression against the Church in Tarnów by the Nazis during World War II and the heroic attitude of the priests at the time. This article contains excerpts of the archival manuscript by Fr. Adam Kaźmierczyk, confirms the already known facts and is a new voice in the matter.

Keywords:

Father Adam Kaźmierczyk, Seminary in Tarnów, Blessed Father Roman Sitko, World War II, repression against the Church 